\title{
Differences in body composition between affected and nonaffected sides in cerebral palsy football athletes: Preliminary findings \\ Diferencias en la composición corporal entre los lados afectados y no afectados em atletas de fútbol con parálisis cerebral: Resultados preliminares
}

*Osmair Gomes de Macedo, **Carlota Leão da Cunha, ***Vasco Miguel Ferreira, **Maria Filomena Soares Vieira

*Universidade de Brasília-UnB Ceilândia (Brasil), **Universidade de Lisboa (Portugal), *** Futebol Clube do Porto (Portugal)

\begin{abstract}
To verify the symmetry of body composition distribution in cerebral palsy (CP) football players with hemiparesis, was carried out a cross-sectional study with17 football-7-a-side players with $\mathrm{CP}$ and hemiparesis, level I according to the Gross Motion Function Classification System and as class 7 according to the International Federation of CP Football. The body composition was evaluated, on both affected and nonaffected sides, by anthropometry and bioimpedance. As a result, fat free mass weight, limb girths and limb muscular areas were significantly higher on nonaffected side. In addition, fat mass weight, limb skinfolds and lower limb fat areas were significantly lower on nonaffected side, but the arm fat area are similar on both sides. These findings suggested that physical requirements of training and competitions of 7 -a-side-football allows the muscular development in the non-affected side, however, they are not enough for the muscular development in the affected side to reach a similar development to the non-affected side.
\end{abstract}

Key words: football-7-a-side, paralympic sports, anthropometry, bioimpedance

Resumen: Para verificar la simetría de la distribución de la composición corporal en jugadores de fútbol con parálisis cerebral (PC) y hemiparesia, se realizó un estudio transversal con 17 jugadores de fútbol 7 con PC y hemiparesia, nivel I según el Gross Motion Function Classification System, y como clase 7 según la International Federation of CP Football. La composición corporal se evaluó, tanto en el lado afectado como en el no afectado, mediante antropometría y bioimpedancia. Como resultado, el peso de la masa libre de grasa, la circunferencia de las extremidades y las áreas musculares de las extremidades fueron significativamente mayores en el lado no afectado. Además, el peso de la masa grasa, los pliegues cutáneos de las extremidades y las áreas de grasa de las extremidades inferiores fueron significativamente menores en el lado no afectado, pero el área de grasa del brazo es similar en ambos lados. Estos resultados sugirieron que los requisitos físicos del entrenamiento y las competiciones de fútbol 7 permiten el desarrollo muscular en el lado no afectado, sin embargo, no son suficientes para que el desarrollo muscular del lado afectado alcance un desarrollo similar al del lado no afectado.

Palabras clave: fútbol 7, deportes paraolímpicos, antropometría, bioimpedancia.

\section{Introduction}

Cerebral Palsy (CP) is described by Rosenbaum et al. (2007) as «... a group of permanent disorders of the development of movement and posture, causing activity limitations, that are attributed to a non-progressive disturbances that occur in the developing fetal or infant brain. The motor disorders of $\mathrm{CP}$ are often accompanied by disturbances of sensation, perception, cognition, communication and behavior, by epilepsy and by secondary musculoskeletal problems».

The most common clinical type of $\mathrm{CP}$ is the spastic or pyramidal, which corresponds to $75 \%$ of $\mathrm{CP}$ cases,

Fecha recepción: 10-06-21. Fecha de aceptación: 16-11-21

Osmair Gomes de Macedo

osmair@unb.br characterized by a deficient syndrome with hyperreflexia and increased tone. Hemiparesis is the anatomical classification present in 25 to $40 \%$ of the cases, characterized by motor impairment mainly in a hemi body usually with negligence (Baladi et al., 2007).

In Western countries, the incidence of $\mathrm{CP}$ is of 2 to 2.5 cases per 1000 live births being one of the most frequent disorders during childhood (Rosembaum, 2014). In Portugal, data from The National Cerebral Palsy Surveillance Program at five years of age, referring to children born between 2001 and 2003, indicate an incidence of 1.61 cases per 1000 live births (Virella et al., 2018).

The prevalence of $\mathrm{CP}$ in adulthood has been increasing, in part due, to the higher survival rates of preterm and/or low birth weight infants and the increased adult longevity, in this sense, it is estimated 
that the prevalence of $\mathrm{CP}$ in adulthood is of 3 cases per 1000 live births (Tossi \& Rosenbloom, 2014).

Although the incidence of $\mathrm{CP}$ in adult age has increased, there are more researches in children with CP than in adults.

Football-7-a-side or CP football, is one of the paralympic modalities for people with $\mathrm{CP}$ and brain injury, where the players are classified according their impairment profile and to severity of their impairment (Peña Gónzalez et al., 2021), and in Brazilian team, the spastic hemiparesis is the most prevalent type of $\mathrm{CP}$ among athletes (Andrade et al., 2005).

There are few studies in adult CP athletes and, to our knowledge, there are only two studies that evaluated CP football athletes with hemiparesis (Andrade et al, 2005, Steenberger, \& van der Kamp, 2008), but none of them investigated the distribution of body composition on the affected and nonaffected side.

$\mathrm{CP}$ children with hemiparesis have different lean mass values when the right and left sides are measured by bioimpedance technique (Parker et al., 1993). In adults with hemiparesis some authors show that the affected side have a greater amount of subcutaneous adipose tissue (Macedo et al., 2008), lower bone mineral content in the upper limbs, and lower lean mass and higher fat mass in the lower limbs (Macedo, 2008). Other studies, in post-stroke spastic hemiplegic adults, reveals that the wandering patients have greater amount of adipose tissue in the affected upper limb, while bedridden individuals present a greater amount of adipose tissue throughout the affected side (Macedo et al., 2012; Silva, 2013).

Based on the aforementioned studies one question arises: If the level of mobility is related to different patterns of body composition distribution, how will this distribution occur in football-7-a-side players with hemiparesis?

With this study we intend to verify the symmetry of body composition distribution in football-7-a-side players.

\section{Material and Methods}

\section{Participants}

Seventeen football-7-a-side players with CP and hemiparesis were recruited from the only three teams enrolled in the 2016 Portuguese National Championship of Football-7-a-side (Futebol Clube do Porto A, Futebol Clube do Porto B and Associação de Boccia Luís Silva Famalicão). The three teams had a total of 17 athletes with hemiparesis and all accepted to participate giving their written informed consent prior to the start of the study.

All athletes were classified as level I according to the Gross Motion Function Classification System (GMFCS) (Hiratuka et al., 2010) and as class 7 according to the International Federation of CP Football (IFCPF) classification.

The criteria for inclusion were: (a) male athletes; (b) age between 18 and 37 years; (c) CP with hemiparesis; (d) at least two years of competitive practice of football-7-a-side; (e) three times a week of training.

Exclusion criteria: Athletes with BMI above 25.9 $\mathrm{kg} \cdot \mathrm{m}^{-2}$ and fat percentage above $20 \%$, athletes with hemiparesis due to sequela of other diseases other than $\mathrm{CP}$, athletes with monoparesis, triparesis, paraparesis, diparesis and tetraparesis and athletes with ataxia, athetosis, stiffness and dystonia that may interfere in the evaluation.

All participants were volunteers and signed an informed consent form before starting the study. The protocols and procedures of this cross-sectional, observational and analytical study followed the Helsinki declaration principles and were approved by the Ethical Committee of the Faculty of Human Kinetics of the University of Lisbon (CEFMH n $\left.{ }^{\circ} 7 / 2016\right) »$.

\section{Procedures}

Anthropometric measurements were taken including body mass, height, eight skinfolds (biceps, triceps, subscapular, iliac crest, supraspinale, abdominal, front thigh and medial calf), and three girths (arm relaxed, mid-thigh and calf). Were used a digital scale (Wiso-W939) and a portable stadiometer (WCS-Wood Compact Body) to measure, respectively, body mass and height, a scientific caliper (Cescorf-Mitutoya) to obtain skinfolds, and an anthropometric tape (Rosscraft) to measure girths. Each measurement was taken, from the affected and nonaffected side, three times, in a single day, before training and the mean value was used for analysis. All anthropometric data were obtained according to the International Society for the advancement of Kinanthropometry (ISAK) standards (Stewart et al., 2011) by one level 1 ISAK anthropometrist.

Based on these data was calculated the body mass index (BMI, $\mathrm{kg} / \mathrm{m}^{2}$ ), the sum of 8 skinfolds, and the muscular and fat areas of three regions (arm, thigh and calf) using the equations proposed by Frisancho (2008). 
The body composition was evaluated by bioimpedance analyzer (BIA) (Maltron BF-900). This BIA measure the total resistance of the body by the passage of an electric current of 500 to 800 microamps and 50 $\mathrm{kHz}$, by means of a tetrapolar system, using two electrodes in the dorsal region of the hand and two in the dorsal region of the foot. Even though this BIA device automatically provides results for percentage of fat mass, percentage of recommended fat mass, body resistance and basal metabolic rate, we only used the resistance value $(R)$ to calculate fat-free mass and fat mass (fat mass = body mass - fat free mass), in the affected and nonaffected side. To determine the fat-free mass we used the equation proposed by Sun et al. (2003) (-10.678+ 0.652 Stature $^{2} / \mathrm{R}_{50}+0.262$ Body Mass $\left.+0.015 \mathrm{R}\right)$. This equation was developed in the RJL-101 equipment to evaluate males aged between 12 and 94 and was validated using the four compartments technique (Mialich et al., 2014). Rodrigues et al. (2001) demonstrated that there is no statistically significant difference when comparing the RJL-101 and Maltron BF-900 devices and also demonstrated that of four equipment compared, the Maltron BF-900 was the one that presented the highest agreement and association rates with the weighing hydrostatic.

Athletes allowed not to using diuretics for seven days before the test; eating for, at least, four hours before the test; drinking alcohol within 48 hours prior to the test; performing strenuous physical activities in the 24 hours prior to the test. Furthermore, the athletes must urinate at least 30 minutes before the test and remain five to ten minutes resting in the supine position before the test.

\section{Statistical analysis}

Descriptive statistics (mean and standard deviation) were computed for all variables. Data were assessed for normality with the Kolmogorov Smirnov test. The $t$ test for paired samples was used to assess differences between the affected and nonaffected side. All analysis was performed with SPSS version 16.0. The alpha value was set at $\mathrm{P}<0.05$.

\section{Results}

This study was designed as a cross-sectional survey of Football 7-a-side-male athletes. The total sample consisted of seventeen athletes with hemiparesis, which corresponded to the total number of athletes with hemiparesis enrolled in the 2016 Portuguese National
Championship of Football-7-a-side. Of these, we excluded, two athletes that shows BMI above $25.9 \mathrm{~kg} . \mathrm{m}^{-}$ 2 and fat percentage over $20 \%$, three athletes that have less than two years of football practice; one athlete for having edema in one of the lower limbs due to orthopedic surgery sequel; and one athlete for hemiparesis as a cranial trauma at age 14. This resulted in a final sample of 10 players.

The mean age of the group was $25.6 \pm 6.05$ years, ranging from 18 to 36 years, mean height was $174.7 \pm$ $3.25 \mathrm{~cm}$, ranging from 170.5 to $190.5 \mathrm{~cm}$, the mean body mass was $68.85 \pm 6.22 \mathrm{~kg}$, ranging from 61.2 to $84.3 \mathrm{~kg}$ and the mean BMI was $22.56 \pm 2.02 \mathrm{~kg} \cdot \mathrm{m}^{-2}$, ranging from 19,66 to $25.87 \mathrm{~kg} \cdot \mathrm{m}^{-2}$ (Table1).

The comparison between the affected and nonaffected side (Table 2) shows significant differences for limb skinfolds (biceps, triceps, front thigh, calf), sum of eight skinfolds, limb girths (arm relaxed, thigh, calf), and muscular and fat areas (arm, thigh, calf) with exception of the arm fat area.

In relation to bioimpedance results, we found significant differences for resistance, fat free mass and fat mass, when compared the affected and nonaffected sides (Table 3).

\begin{tabular}{|c|c|c|c|c|c|c|c|c|c|}
\hline \multicolumn{10}{|c|}{$\begin{array}{l}\text { Table } 1 \\
\text { Athletes characteristics }\end{array}$} \\
\hline Athlete & Age & $\begin{array}{c}\text { Mass } \\
(\mathrm{Kg})\end{array}$ & $\begin{array}{l}\text { Height } \\
(\mathrm{cm})\end{array}$ & $\begin{array}{c}\text { BMI } \\
\left(\mathrm{kg} / \mathrm{m}^{2}\right)\end{array}$ & $\begin{array}{l}\text { Years of } \\
\text { Practice }\end{array}$ & Class & $\begin{array}{c}\text { Competition } \\
\text { Level }\end{array}$ & $\begin{array}{c}\text { Ashwort } \\
\text { Scale }\end{array}$ & $\begin{array}{c}\text { Side } \\
\text { Affected }\end{array}$ \\
\hline 1 & 26 & 70.3 & 176.5 & 21.9 & 4 & 7 & Internacional & 1 e 2 & Right \\
\hline 2 & 32 & 65.9 & 172 & 22.29 & 11 & 7 & Nacional & 1 e 2 & Right \\
\hline 3 & 19 & 61.6 & 177 & 19.66 & 7 & 7 & Internacional & 1 e 3 & Right \\
\hline 4 & 36 & 64.3 & 173.5 & 21.37 & 13 & 7 & Internacional & 1 e 1 & Right \\
\hline 5 & 32 & 70.8 & 179 & 22.1 & 20 & 7 & Internacional & 1 e 3 & Right \\
\hline 6 & 31 & 72.4 & 170.5 & 24.9 & 19 & 7 & Nacional & 1 e 2 & Left \\
\hline 7 & 18 & 72.6 & 170.5 & 24.97 & 7 & 7 & Internacional & 1 e 2 & Left \\
\hline 8 & 19 & 61.2 & 176 & 19.76 & 4 & 7 & Nacional & 1 e 3 & Left \\
\hline 9 & 23 & 84.3 & 180.5 & 25.88 & 2 & 7 & Nacional & 1 e 3 & Right \\
\hline 10 & 20 & 65.1 & 171.5 & 22.15 & 3 & 7 & Internacional & 1 e 3 & Left \\
\hline Mean & 25.6 & 68.85 & 174.7 & 22.5 & 9 & - & - & - & - \\
\hline $\mathrm{SD}$ & 6.34 & 6.53 & 3.41 & 2.02 & 6.53 & - & - & - & \\
\hline \multicolumn{10}{|c|}{ SD-standard deviation; BMI-body mass index } \\
\hline \multicolumn{10}{|l|}{ Table 2} \\
\hline \multicolumn{10}{|c|}{ Comparison of anthropometric variables between nonaffected and affected sides. } \\
\hline \multicolumn{5}{|c|}{ Skinfolds (mm) } & NAS & & AS & $\mathrm{p} \mathrm{va}$ & lue \\
\hline \multicolumn{5}{|c|}{ Biceps } & 3.34 & & 4.09 & 0.00 & $03 *$ \\
\hline \multicolumn{5}{|c|}{ Triceps } & 8.03 & & 10.07 & 0.00 & 04* \\
\hline \multicolumn{5}{|c|}{ Subscapular } & 9.27 & & 9.76 & 0.3 & 27 \\
\hline \multicolumn{5}{|c|}{ Iliac Crest } & 14.13 & & 14.02 & 0.9 & \\
\hline \multicolumn{5}{|c|}{ Supraspinale } & 6.90 & & 7.60 & 0.2 & 30 \\
\hline \multicolumn{5}{|c|}{ Abdominal } & 15.44 & & 15.88 & 0.1 & 47 \\
\hline & & Front Thi & & & 12.81 & & 15.49 & 0.00 & $03 *$ \\
\hline & & Medial C & & & 7.30 & & 9.57 & 0.00 & \\
\hline & & Sum & & & 77.21 & & 86.46 & 0.00 & $02 *$ \\
\hline & & Girth (cr & & & NAS & & AS & p va & lue \\
\hline & & $\mathrm{rm}(\mathrm{rela})$ & & & 28.37 & & 25.42 & $<0.0$ & $01 * *$ \\
\hline & & Thigh & & & 54.1 & & 50.37 & $<0.0$ & $01 * *$ \\
\hline & & Calf & & & 36.97 & & 33.69 & $<0.0$ & $01 * *$ \\
\hline & & scle area & $\left.\mathrm{cm}^{2}\right)$ & & NAS & & AS & $\mathrm{p}$ va & lue \\
\hline & & Arm & & & 53.48 & & 39.73 & $<0.0$ & $01 * *$ \\
\hline & & Thigh & & & 200.13 & & 165.51 & $<0.0$ & $01 * *$ \\
\hline & & Calf & & & 95.99 & & 75.43 & $<0.0$ & $01 * *$ \\
\hline & & at area $(c$ & & & NAS & & AS & p va & lue \\
\hline & & Arm & & & 10.96 & & 12.08 & 0.1 & 04 \\
\hline & & Thigh & & & 33.47 & & 37.13 & 0.02 & $21 *$ \\
\hline & & Calf & & & 13.20 & & 15.31 & 0.0 & \\
\hline $\mathrm{NAS}=\mathrm{n}$ & nonaffec & ted side; & $\mathrm{AS}=$ affec & cted side; & *significant & it at $\mathrm{p}$ & $0.05 ; * *$ signific & icant at $\mathrm{p}<$ & 0.001 . \\
\hline Tabela 3 & & & & & & & & & \\
\hline Compari & rison of & bioimpe & ance vari & iables bety & veen affecte & ed and & nonaffected side & & \\
\hline & Bioin & npedanc & & & NAS & & AS & $\mathrm{p} \mathrm{v}_{\mathrm{z}}$ & alue \\
\hline & Resis & tance $(\mathrm{R}$ & & & 479. & & 607.6 & $<0,0$ & $01 * *$ \\
\hline & Fat fre & e mass $(K$ & & & 58.7 & & 52.84 & $<0,0$ & $01 * *$ \\
\hline & Fat $n$ & nass $(\mathrm{Kg})$ & & & 10.1 & & 16.01 & $<0,0$ & $01 * *$ \\
\hline
\end{tabular}




\section{Discussion}

The purpose of the present study was to verify the symmetry of body composition distribution in football7-a-side players with hemiparesis.

Several studies have shown that muscular deficits can alter the deposit of fat in the affected extremities, resulting in unreal body composition (Hildreth et al., 1997; Macedo et al., 2008; Macedo, 2008; Parker et al., 1993; Runciman et al., 2016; Silva, 2013).

In people with spastic hemiplegia after stroke, the comparison between the affected and nonaffected sides demonstrated different results according to the functionality of the people. In ambulatory people, significant statistical differences are observed only in the biceps and triceps skinfolds (Macedo et al., 2012). On the other hand, in those with spastic hemiplegia post-stroke, significant statistical differences were observed between the affected and nonaffected sides in all skinfolds analyzed (biceps, triceps, subscapular, axillary-middle, pectoral, abdominal, suprailiac, thigh and calf) and percentage of fat (Silva, 2013).

In adults with $\mathrm{CP}$ and spastic hemiplegia, one study showed statistically significant differences between the biceps, triceps, pectoral, supra-iliac, and medial calf skinfolds, and between the fat percentage estimated by the Guedes and Jackson-Pollock equations (seven and three skinfolds), when comparing the affected and nonafeccted sides. It also showed that the difference between the skinfolds and between the percentage of fat of the affected and nonaffected sides is higher than in the control group (Macedo et al., 2008).

As expected, our results in football-7-a-side athletes with hemiparesis confirmed the previous findings. We verify that limb skinfolds (biceps, triceps, front thigh) and sum of the trunk and limbs skinfolds are significantly smaller in the affect side in comparison with the nonaffected side. Although fat areas, determined by the Frisancho equation, were smaller in the affected limb, there were only significant differences in lower limb (thigh and calf).

Silva (2013) found significant differences in the percentage of fat obtained by bioimpedance between the dominant and non-dominant sides in post-stroke spastic hemiplegia patients. Similarly, data of our study showed significantly smaller fat mass, using bioimpedance, in the nonaffected side.

In contrast with our results, Runciman et al. (2016) did not found statistically significant differences in fat mass between the affected and nonaffected sides, in six paralympic athletes with $\mathrm{CP}$ and hemiparesis, using dualenergy X-ray absorptiometry (DEXA). However, they found that both the upper and the lower limb fat free soft tissue mass were significantly lower on the affected side compared to the nonaffected side. We also found significantly lower values for fat free mass, limb girths and limb muscular areas on the affected side.

Although the BMI was used only for characterization of sample and two athletes was excluded from the research that shows BMI above $25.9 \mathrm{~kg} \cdot \mathrm{m}^{-2}$ and fat percentage over $20 \%$, the mean BMI of athletes with hemiparesis $(22.56 \pm 2.02)$ was similar to the BMI found by Gorla et al. (2018) in Brazilian football-7-a-side athletes of all classes $(22.8 \pm 2.24)$.

The limitations of the study include a small sample size, since there were only three teams enrolled in the National Championship of Portugal in 2016 and the absence of a control group of people with sedentary hemiparesis. To assess body composition, were not use a gold standard technique but two techniques used in clinical practice (anthropometry and bioimpedance). It is suggested to conduct future studies with a larger number of football-7-a-side players with $\mathrm{CP}$ and hemiparesis that includes a control group of individuals with inactive $\mathrm{CP}$ and hemiparesis to verify the effect of practice of football-7-a-side on the distribution of body composition.

\section{Conclusion}

These preliminary findings showed asymmetries in fat and fat free mass distribution between the affected and nonaffected side in football-7-a-side athletes with hemiparesis. Fat mass, assessed by bioimpedance and anthropometry, was lower in nonaffected side, contrary fat free mass and muscular areas were higher. These findings suggested that physical requirements of training and competitions of 7-a-side-football allows the muscular development in the nonaffected side, however, they are not enough for the muscular development in the affected side to reach a similar development to the nonaffected side.

\section{Acknowledgements}

Conselho Nacional de Desenvolvimento Científico e Tecnológico do Brasil (CNPq. N.234769/2014-0), Futebol Clube do Porto and Associação de Boccia Luís Silva - Famalicão. 


\section{References}

Andrade, M. S., Fleury, A. M., \& Silva, A. C. (2005). Força muscular isocinética de jogadores de futebol da seleção paraolímpica brasileira de portadores de paralisia cerebral. Revista Brasileira de Medicina do Esporte, 11(5), 281-285. https: / / doi:org/10.1590/S151786922005000500007

Baladi, A. B. P.T., Castro, N. M. D., \& Moraes Filho, M. C. (2007). Paralisia Cerebral. In: Fernandes, A. C., Ramos,A.C. R., Casalis, M. E. P., \& Hebert, S. K. (Eds.) AACD Medicina e Reabilitação: Princípios e Prática (pp. 16-34). Porto Alegre: Artes Médicas.

Frisancho, A. R. (2008). Anthropometric standards: an interactive nutritional reference of body size and body composition for children and adults. Ann Arbor, MI:The University of Michigan Press.

Gorla, J. I., Nogueira, C. D., Gonçalves, H. R., De Faria, F. R., Buratti, J. R., Nunes, N., Pereira do Rêgo, J.T., Borges, M., Vieira, I. B., \& Labrador Roca, V. (2019). Composición corporal y perfil somatotípico de jugadores brasileños de fútbol siete con Parálisis Cerebral de acuerdo con la clasificación funcional. Contribución al Deporte Paralímpico. Retos, 35, 326-328. https://doi.org/ 10.47197/retos.v0i35.58931

Hildreth, H. G., Johnson, R. K., Goran, M. I., \& Contompasis, S. H. (1997). Body composition in adults with cerebral palsy by dualenergy X-ray absorptiometry, bioelectrical impedance analysis, and skinfold anthropometry compared with the $18 \mathrm{O}$ isotopedilution technique. The American Journal of Clinical Nutrition, 66(6), 1436-1442. https://doi:org/10.1093/ajcn/66.6.1436

Hiratuka, E., Matsukura,T. S., \& Pfeifer, L. I. (2010). Cross-cultural adaptation of the Gross Motor Function Classification System into Brazilian-Portuguese (GMFCS). Brazilian Journal of Physical Therapy, 14(6), 537-544. https://doi:org/10.1590/S141335552010000600013

Kuczmarski, R. J., Flegal, K. M., Johnson, C. L., \& Hubbard, V. S. (2003). Development of bioelectrical impedance analysis prediction equations for body composition with the use of a multicomponent model for use in epidemiologic surveys. The American Journal of Clinical Nutrition, 77(2), 331-340. https:/ / doi:org/10.1093/ajcn/77.2.331

Macedo, O. G., Carazzato, J. G., Meirelles, E. S., de Paula, A., dos Santos, C. A., Bolliger Neto, R., \& Mattar Júnior, R. (2008). Comparative study of skin folding of dominant and nondominant hemibodies in spastic hemiplegic cerebral palsy. Clinics, 63(5), 601-606. https://doi:org/10.1590/S180759322008000500006

Macedo, O. G. (2008). Comparative study of body composition by dual $\mathrm{X}$ rays densitometry in the dominant and nondominant hemi bodies between spastic hemiplegic and normal persons. Doctoral dissertation, University of São Paulo, São Paulo, Brazil. Retrieved July 17, 2020,from: https: / /www.teses.usp.br/teses/ disponiveis / 5/5160/tde-17122008-085802/publico/ osmairgdemacedo.pdf

Macedo, O. G., Silva, E. F., Lima, M. S. N., Barbosa, P. H. F. A., \& Martins, E. F. (2012). Estudo comparativo entre as dobras cutâneas dos hemicorpos dominante e não dominante em pessoas com hemiplegia espástica pós-acidente vascular encefálico. Anais do 2o Congresso Brasileiro de Fisioterapia Neurofuncional - 2 COBRAFIN, Rio de Janeiro, Brazil. Brazilian Journal of Physical Therapy, 16(2), 168-168. Retrieved July 17, 2020, from: https: / /abrafin.org.br/wp-content/uploads/2015/02/COBRAFINII.pdf
Mialich, M. S., Sicchieri, J. M. F., \& Jordão Junior, A. A. (2014) Analysis of Body Composition: A Critical Review of the Use of Bioelectrical Impedance Analysis. International Journal of Clinical Nutrition, 2(1), 1-10. https: / / doi:org/10.12691/ijcn-2-1-1

Parker, D. F., Carriere, L., Hebestreit, H., Salsberg, A., \& Bar-Or, O. (1993). Muscle performance and gross motor function of children with spastic cerebral palsy. Developmental Medicine and Child Neurology, 35(1), 17-23. https://doi:org/10.1111/j.14698749.1993.tb11547.x

Peña Gónzalez, I., Sarabia, J. M., Mancha-Triguero, D., Moya-Ramón, M., \& Gamonales, J. M. (2021). Relación entre el rendimiento físico y la carga de trabajo en partido y efecto de dos partidos consecutivos en futbolistas con parálisis cerebral (Relationship between physical performance and match load and effects of two consecutive matches in cerebral. Retos, 41, 728734. https://doi.org/10.47197/retos.v41i0.86424

Rodrigues, M. N., Silva, S. C. Monteiro, W. D., \& Farinatti, P.T.V. (2001). Estimativa da gordura corporal através de equipamentos de bioimpedância, dobras cutâneas e pesagem hidrostática. Revista Brasileira de Medicina do Esporte, 7(4), 125-131. https://doi.org/ 10.1590/S1517-86922001000400003

Rosenbaum, P., Paneth, N., Leviton, A., Goldstein, M., \& Bax, M. (2007). The definition and classification of Cerebral Palsy. Developmental Medicine and Child Neurology, 49(s109), 1-44. https: / /doi.org/10.1111/j.1469-8749.2007.00001.x

Runciman, P.,Tucker, R., Ferreira, S., Albertus-Kajee,Y., Micklesfield, L., \& Derman,W. (2016). Site-Sspecific bone mineral density is unaltered despite differences in fat-free soft tissue mass between affected and nonaffected sides in hemiplegic paralympic athletes with cerebral palsy: Preliminary findings. American Journal of Physical Medicine \& Rehabilitation, 95(10), 771-778. https://doi.org/ 10.1097/PHM.0000000000000532

Silva, E. F. (2013). Profile of body composition in people bedridden with spastic hemiplegic and distribution of lean and fat mas in the hemibodies. Monography, University of Brasília, Brasília, Brazil. Retrieved July 17, 2020, from https://bdm.unb.br/handle/ $10483 / 6375$

Steenberger, B., \& van der Kamp, J. (2008). Attentional processes of high-skilled soccer players with congenital hemiparesis: differences related to the side of the hemispheric lesion. Motor Control, 12(1), 55-66. https://doi.org/10.1123/mcj.12.1.55

Stewart, A., Marfell-Jones, M., Olds, T., \& Ridder, H. (2011). International standards for anthropometric assessment. Lower Hutt, NZ: ISAK.

Sun, S. S., Chumlea, W. C., Heymsfield, S. B., Lukaski, H. C., Schoeller, D., Friedl, K., Kuczmarski, R. J., Flegal, K. M., Johnson, C. L., \& Hubbard,V. S. (2003). Development of bioelectrical impedance analysis prediction equations for body composition with the use of a multicomponent model for use in epidemiologic surveys. The American journal of clinical nutrition, 77(2), 331-340. https:// doi.org/10.1093/ajcn/77.2.331

Tosi, L., \& Rosenbloom, L. (2014). Cerebral palsy in adulthood. In: Dan, B., Mayston, M., \& Paneth, N. (Eds.), Cerebral palsy: Science and clinical practice (pp. 49-62). Mac Keith Press.

Virella, D., Folha, D., Andrada, M. G., Cadete, A., Gouveia, R., Gaia,T., Alvarelhão, J., \& Calado, E. (2018). Vigilância Nacional da Paralisia Cerebral aos 5 anos de Idade- Crianças Nascidas entre 2001 e 2007. Lisbon: Federação das Associações Portuguesas de Paralisia Cerebral. Retrieved July 17, 2020, from: http:// www.fappc.pt/wp-content/uploads/2018/02/ FAPPC_PROJETO167_LivroIledicao_PVNPC5A.pdf 